\title{
«The good physician treats the disease; The great physician treats the patient who has the disease»
}
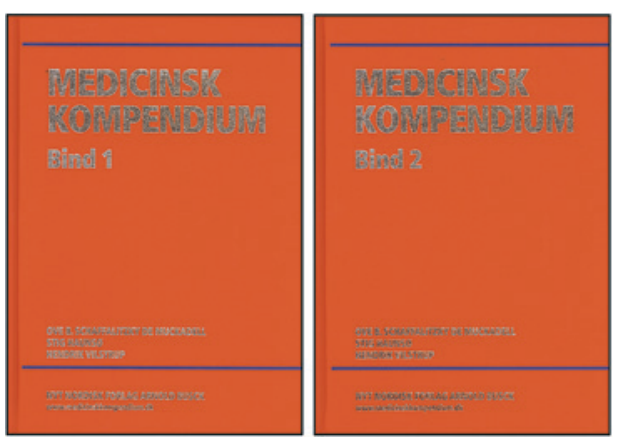

Ove B. Schaffalitzky de Muckadell, Stig Haunsø, Hendrik Vilstrup, red. Medicinsk kompendium

2 bd. 18. utg. 2958 s , tab, ill. København: Nyt Nordisk Forlag Arnold Busck, 2013. Pris DKK 4000

ISBN 978-87-17-04239-1

Den danske, indremedisinske klassikeren Medicinsk kompendium foreligger nå i en feiende flott oransje 18. utgave, kun fire år etter at den 17. utgaven kom ut, og forfatterne starter sitt forord med ovenstående sitat av Willam Osler. Et kompendium er definert som en samling av konsis, men detaljert informasjon om et spesifikt emne. Førsteutgaven av Medicinsk kompendium, utgitt i 1935 og basert på forelesningsnotatene til den unge, danske legen Erik Hagen og den fortsatt medisinstuderende barndomsvennen Ole Bernth, var nok tro mot denne definisjonen. Å kalle den nye utgaven, som teller nær 3000 sider fordelt på to bind, for et kompendium er vel en underdrivelse, og kanskje et uttrykk for kledelig skandinavisk beskjedenhet. Men ambisjonene bak verket er ikke beskjedne. Hovedredaktørene for det danske tobindsverket, gastroenterologene Ove B. Schaffalitzky de Muckadell og Henrik Vilstrup, henholdsvis fra Syddansk Universitet i Odense og Aarhus Universitetshospital, og kardiologiprofessor Stig Haunsø fra Rigshospitalet i København, har sammen med mer enn 170 medforfattere (hvorav to norske: Gunnar Husby og Stein Kaasa) satt seg det ambisiøse mål å dekke alle aspekter av indremedisin på et høyt kvalifisert og detaljert nivå.

Tobindsverket er tenkt å dekke behovene både til en lærebok for medisinerstudenter og til en håndbok for leger og spesialister. Sånn sett konkurrerer Medicinsk kompendium på den ene side med andre indremedisinske bibler som Harrison's principles of internal medicine og Oxford textbook of medicine og på den andre side med andre, mindre ambisiøse skandinaviskspråklige bøker. Mitt inntrykk som lærer for medisinstudenter i indremedisin gjennom mange år er at det er få norske studenter som velger de mest omfattende lærebøkene, og at disse i hovedsak benyttes som oppslagsverk i vårt land. I en tid da den medisinske utviklingen synes å skje stadig raskere, og da nye generasjoner studenter og nyutdannede leger i vesentlig grad innhenter medisinsk informasjon via internett, er det betimelig å spørre hvorvidt det er plass til og behov for en ny utgave av et slikt «magnum opus».

Førsteinntrykket er positivt. Layouten er tiltalende, og teksten gir et grundig, men ikke kompakt inntrykk og mykes opp av mange illustrasjoner og instruktive figurer og diagrammer. Med så mange forfattere sier det seg selv at formen vil variere noe, men generelt er kapitlene bygd over samme lest. Boken er skrevet på et moderne dansk, som er lett å lese, også for en nordmann. Ifølge redaktørene er denne utgaven blitt grundig revidert, oppdatert og modernisert. Sammenliknet med tidligere utgaver inneholder denne således tidsriktig bonusmateriale, som QR-koder som gir adgang til for eksempel hjerteauskultasjonsopptak, ekkokardiografiske registreringer og videopptak av undersøkelser og undersøkelsesteknikk. Videre kan illustrasjoner, diagrammer, røntgen- og skanningbilder i høy oppløsning lastes ned til personlige datamaskiner eller nettbrett. Ifølge forordet er det også planlagt en elektronisk versjon.

Verket er inndelt i innledende kapitler om generelle sykdomsaspekter, som «Lægens kontakt med patienten», «Grundlag for kliniske beslutninger - evidensbaseret medicin» og «Klinisk epidemiologi», etterfulgt av kapitler som omtaler biologiske grunnbegreper, så som «Inflammation og innat immunitet», «Neoplasi» og «Medicinsk genetik». Derpå følger en del kalt «Kliniske kardinalmanifestationer», som blant annet inneholder kapitler om oftalmologiske og dermatologiske manifestasjoner ved medisinske sykdommer, den akutt psykotiske pasient, somatoforme lidelser og funksjonelle syndromer. Det finnes også egne deler som omhandler rettsmedisin og rettspsykiatri, klinisk farmakologi og klinisk biokjemi, alternativ behandling og leksikale opplysninger. Hoveddelen av boken er den som er kalt «Kliniske sygdomsenheder», og som er inndelt etter ulike sykdommer. Noen kapitler er omfattende og med mange forfattere, som for eksempel kapitlet om hjertesykdommer (18 forfattere) og kapitlet om lungesykdommer (20 forfattere), mens andre kapitler er smalere og mer spesifikke, som kapitlene om amyloidose og porfyri. Det er ikke umiddelbart klart hvorfor man har valgt å samle hjerte, lunge og nyresykdommer i hvert sitt kapittel, mens mage-tarm-sykdommer og endokrine sykdommer er spredt på mange kapitler.

Samlet sett er den nye utgaven av Medicinsk kompendium en stor, faglig god og pedagogisk skrevet lærebok i indremedisin som trygt kan anbefales for medisinstudenter. Som oppslagsbok for leger i spesialisering mangler den nok noe på detaljeringsnivået sammenliknet med de fremste engelskspråklige konkurrentene. At den er skandinaviskspråklig, er både en fordel og en ulempe. På den ene siden samsvarer danske behandlingstradisjoner på en del felt, slik som antibiotikabehandling, bedre med de norske tradisjonene enn det angloamerikanske vil gjøre. På den andre siden betyr dansk språk at boken kun er aktuell i det skandinaviske markedet, og det relativt sett beskjedne opplaget gjør at prisen blir høy. I en tid da informasjonsstrømmen er ufattelig stor, og der ny viten ofte presenteres fragmentarisk, er det etter min mening fortsatt behov for lærebøker som Medicinsk kompendium. Uansett kan man ikke annet enn å la seg imponere over at våre danske kolleger nok en gang har levert en fremragende indremedisinsk lærebok i stort format, og vi må allerede nå ønske dem «held og lykke» med arbeidet med neste utgave.

Torbjørn Omland

Professor, Institutt for klinisk medisin, Universitetet i Oslo 